\title{
Sexual Desire, Mood, Attachment Style, Impulsivity, and Self-Esteem as Predictive Factors for Addictive Cybersex
}

Nektaria Varfi, MD; Stephane Rothen, PhD; Katarzyna Jasiowka, MA; Thibault Lepers, MA; Francesco Bianchi-Demicheli, MD; Yasser Khazaal, MD

Geneva University Hospitals, Geneve, Switzerland

Corresponding Author:

Yasser Khazaal, MD

Geneva University Hospitals

Grand Pré 70 C

Geneve, 1206

Switzerland

Phone: 410766792018

Fax: 41223202840

Email: yasser.khazaal@hcuge.ch

\section{Abstract}

Background: An increasing number of studies are concerned with various aspects of cybersex addiction, the difficulty some persons have in limiting cybersex use despite a negative impact on everyday life.

Objective: The aim of this study was to assess potential links between the outcome variable cybersex addiction, assessed with the Compulsive Internet Use Scale (CIUS) adapted for cybersex use, and several psychological and psychopathological factors, including sexual desire, mood, attachment style, impulsivity, and self-esteem, by taking into account the age, sex, and sexual orientation of cybersex users.

Methods: A Web-based survey was conducted in which participants were assessed for sociodemographic variables and with the following instruments: CIUS adapted for cybersex use, Sexual Desire Inventory, and Short Depression-Happiness Scale. Moreover, attachment style was assessed with the Experiences in Close Relationships-Revised questionnaire (Anxiety and Avoidance subscales). Impulsivity was measured by using the Urgency, Premeditation (lack of), Perseverance (lack of), Sensation Seeking, Positive Urgency Impulsive Behavior Scale. Global self-esteem was assessed with the 1-item Self-Esteem Scale.

Results: A sample of 145 subjects completed the study. Addictive cybersex use was associated with higher levels of sexual desire, depressive mood, avoidant attachment style, and male gender but not with impulsivity.

Conclusions: Addictive cybersex use is a function of sexual desire, depressive mood, and avoidant attachment.

(JMIR Ment Health 2019;6(1):e9978) doi: 10.2196/mental.9978

\section{KEYWORDS}

sex; internet; addictive behavior; impulsivity

\section{Introduction}

\section{Background}

The internet is widely used in everyday life, including for health-related queries [1-4] and sexual health-related purposes [5]. Cybersex is a common behavior that refers to sexually oriented Web-based activities that aim to provide erotic fulfillment or sexual gratification [6]. Cybersex includes various activities such as chatting, dating, searching for offline dates, sexual role-playing, webcam interactions, virtual reality, and pornography. These activities can be categorized as solitary-arousal (ie, watching porn), partnered-arousal (ie, chatting), and nonarousal activities (ie, sex-related information seeking) [7].

Moderate use of cybersex may contribute to the expansion of sexual knowledge and enhance offline intimate interactions and sexual communications with partners [8]. Similar to those who engage in other internet-related behaviors such as gaming [9-11], however, some cybersex users may develop addictive patterns of use with possible negative consequences [12,13]. These patterns are usually described as excessive and poorly controlled use of internet-based sexual activities that lead to problems or functional impairment and persist despite such difficulties $[14,15]$. No consensus has been achieved about the 
conceptualization of this disorder [12,16], although it is often referred to as cybersex addiction [17-20]. Nevertheless, as reported for other internet-related problem behaviors [21], it is probably an umbrella term that refers to different types of cybersex activities (solitary internet porn, sex webcams, chat, etc) and to different mechanisms (ie, positive reinforcement such as sexual gratification and arousal from porn, social rewards from chat, or negative reinforcement through escape from daily stress) [12,22,23].

Several studies have reported similarities between addictive cybersex and other addictive disorders, including reduction in executive prefrontal control (the ability to select actions or thoughts in relation to internal goals) [24], association between subjective pornographic cue-related arousal and excessive cybersex [25,26], association between striatal cue reactivity (neuroimaging showing ventral striatum activity during exposure to cybersex cues) and sexual desire [27], and subjective symptoms of cybersex addiction (feeling a loss of control in using it) [23] and patterns of positive and negative reinforcement of Web-based sexual behaviors [28]. Although it seems to be of scientific significance, research on cybersex addiction is still limited [25]. In particular, factors related to the development and maintenance of addictive cybersex remain understudied [12]. This can partly be explained by the lack of consensus about such behavioral addictions.

Possible determinants of addictive cybersex have nonetheless received preliminary attention. Sexual desire reflects the powers that draw a person toward or away from sexual behavior [29] and motivate people to sexually interact. Yet, despite the importance of sexual desire as a determinant of sexual behaviors $[22,30]$, studies on the association between sexual desire and cybersex are still lacking. In concordance with other reports on behavioral addictions and excessive internet use [9,31], several studies on the psychopathological correlates of addictive use of cybersex frequently described an association with psychiatric disorders such as depressive moods [22]. Low self-esteem was also associated with sexting (sharing sexual photos) [32], compulsive behavior [33], and sexual addiction [34]. In addition, in agreement with other studies on addictive internet gaming [35], some studies suggested that addictive cybersex is at least partly a coping behavior that aims to regulate negative emotions [20,36].

The attachment theory argues that as a result of their childhood interactions with parents and relatives, people develop beliefs about their relations to others that come to shape their future affective, intimate, and sexual relationships and behaviors according to their attachment styles [37]. In particular, they may develop insecure attachment styles. For instance, an avoidant attachment style is linked to discomfort with close relationships, avoidance of affective commitment, and a possible increase in the search for casual interactions. In contrast, anxious attachment is related to anxiety about rejection and abandonment, possibly leading people to overengage in behaviors that aim to ensure partner availability and validation and to repeatedly check for such security [38].

Such adult attachment styles seem to influence sexual experiences, intimate relationships, and sexual behaviors and satisfaction [39]. A positive correlation was previously reported between anxious and avoidant attachment and sexual addiction [40]. Furthermore, it was [41] shown that problematic pornography use is elevated in individuals with emotional insecurities such as anxious or avoidant attachment [42] and traumatic souvenirs of the past [19].

Moreover, impulsivity is a multifaceted psychological and neuropsychological construct leading to the fulfillment of behaviors without careful anticipation [43]. Impulsivity is a transdiagnostic factor involved in addictive behaviors [44], including problem gaming [45] and internet gambling [21]. Nonetheless, to date, the association between addictive cybersex and impulsivity has also received little attention [20], and in those studies that have examined this association, mixed results were found. In some studies, lack of executive prefrontal control $[25,26]$ and impulsivity facets were associated with addictive cybersex [25,26]. In contrast, Wetterneck et al [46] did not find any differences in impulsivity measures between addictive and nonaddictive pornography use.

A recent self-report measure of impulsivity is the Urgency, Premeditation (lack of), Perseverance (lack of), Sensation Seeking, Positive Urgency (UPPS-P) Impulsive Behavior Scale, which has been translated with stable factor structure into numerous languages [47-50]. The acronym is related to the different impulsivity facets assessed by the scale: negative urgency (the tendency to act impulsively when experiencing negative emotions), premeditation (lack of), perseverance (lack of), sensation seeking, and positive urgency (the tendency to act impulsively when experiencing positive emotions). A recent study [20] showed that negative urgency and negative affect interact in predicting addictive cybersex, whereas no other associations were found with the other impulsivity dimensions assessed, such as lack of premeditation, lack of perseverance, or positive urgency (the tendency to act impulsively when experiencing positive emotions).

Despite a possible broader conception, sexual orientation can be described as homosexuality, bisexuality, or heterosexuality [51]. In previous studies, males with a homosexual and a bisexual orientation reported differences in the use of cybersex (more frequent Web-based sexual interactions than those reported by heterosexual males) [52]. Furthermore, people in sexual minority groups, partly due to stigma, are at increased risk of health inequalities, such as addictive disorders [53] and depression [54].

\section{Objectives}

The aim of this study was to assess the links between cybersex addiction and several psychological and psychopathological factors, including sexual desire, mood, attachment style, and impulsivity, by taking into account the age, sex, and sexual orientation (heterosexual, homosexual, or bisexual) of cybersex users. We expected to find an influence of the selected variables on cybersex addiction. 


\section{Methods}

\section{Recruitment Procedure}

The participants consisted of users of cybersex sites and forums recruited via advertising on specialized forums and websites (pornographic sites, chat rooms, and dating sites). To be included, participants had to be more than 18 years old and to understand the languages of the questionnaires (French or English). There was no incentive for participation. The participants gave consent and then completed the questionnaires anonymously via SurveyMonkey links. The survey responses were sent over a secure-Secure Sockets Layer-encrypted connection. Internet protocol addresses were used only to check for double participation. The study did not use the participants' names, nicknames, or email addresses, and the data were analyzed anonymously. The study protocol was approved by the Ethical Committee of the Geneva University Hospitals.

\section{Sample}

The recruitment procedure resulted in 761 people clicking on the link to participate in the study, of whom 605 gave their consent. The participant completion rate decreased along the length of the questionnaire. Among the 605 subjects who gave their consent, 358 continued past the demographics section. Only 226 subjects continued to the last part, the questionnaire section. After missing values were removed, the final sample included 145 participants.

\section{Instruments}

\section{Compulsive Internet Use Scale}

The Compulsive Internet Use Scale (CIUS) [55] consists of 14 items rated on a 5-point Likert scale ranging from 0 (never) to 4 (very often). Higher scores indicate more severe addictive use. Previous studies reported good factorial stability across time and across different samples [55]. The scale involves items related to different aspects of addictive behaviors such as loss of control, preoccupation, withdrawal, coping, and conflict. In different samples and linguistic validations of the CIUS, a 1 -factor solution was repeatedly retained as the best-fit model [55-59]. The items of the CIUS ask about general use of the internet (ie, "Do you find it difficult to stop using the internet when you are online?"). To specifically assess cybersex activities, we asked participants to answer the questions while keeping in mind that the word internet specifically refers to cybersex use. The CIUS and other internet addiction scales have previously been successfully adapted to focus on a specific internet use to assess internet gaming, internet gambling [60], and cybersex $[20,61]$ without alterations of their psychometric properties.

\section{Sexual Desire Inventory}

Consisting of 14 items on a Likert scale, the Sexual Desire Inventory (SDI) was used to evaluate sexual desire (eg, "When you first see an attractive person, how strong is your desire?") [62].

Four items are scored from 0 (not at all) to 7 (more than once a day). The other items are answered on a 9-point Likert scale ranging from 0 (no desire) to 8 (strong desire). Higher SDI scores reveal higher sexual desire.

\section{Short Depression-Happiness Scale}

The Short Depression-Happiness Scale (SDHS) was used to evaluate mood variation from depressive mood (eg, "I felt dissatisfied with my life") to happiness (eg, "I felt happy") during the last 7-day period. It consists of 6 items, 3 positive and 3 negative, rated on a 4-point Likert scale ranging from 0 (never) to 3 (often). The lower the score, the higher the depressive symptoms [63].

\section{Experiences in Close Relationships-Revised Questionnaire}

This Experiences in Close Relationships-Revised (ECR-R) questionnaire was used to evaluate attachment style [64,65]. The inventory includes 18 items for anxious attachment characterized by possessive love and fear of loss (eg, "I often worry that my partner will not want to stay with me") and 18 items for avoidant attachment characterized by fear of romantic love and low relationship success (eg, "I prefer not to show a partner how I feel deep down"). The items are rated on a 7-point Likert scale ranging from 1 (completely disagree) to 7 (completely agree). Several studies showed good test-retest reliability and a good association of the subscale scores with other ratings of daily anxiety and avoidance faced with a close companion [66].

Urgency, Premeditation (Lack of), Perseverance (Lack of), Sensation Seeking, Positive Urgency) Impulsive Behavior Scale Impulsive Behavior Scale

The UPPS-P Impulsive Behavior Scale [67], in its short 20-item version [47], is used to measure impulsivity according to 5 dimensions: positive urgency (strong reactions while experiencing intense positive emotions), negative urgency (strong reactions while experiencing intense negative emotions, eg, "When I am upset I often act without thinking"), lack of premeditation (tendency to disregard the consequences before acting), lack of perseverance (difficulty staying focused on a difficult or boring task), and sensation seeking. Responses are rated on a 4-point Likert scale ranging from 1 (strongly agree) to 4 (totally disagree). Good test-retest stability was previously reported [47]. In consideration of its multicomponents, the scale was of particular interest for the assessment of addictions [68]. In some studies, some of the impulsivity facets assessed with the UPPS-P, in particular negative urgency [69-72] and, depending on the assessed behaviors and sample, positive urgency [71], lack of premeditation [69], lack of perseverance [73], and sensation seeking [68], were previously associated with addictive behaviors.

\section{Single-Item Self-Esteem Scale}

This 1-item scale ("I have high self-esteem") was used to measure global self-esteem [74]. Participants complete the single item on a 5-point Likert scale ranging from 1 (not very true of me) to 5 (very true of me). The Single-Item Self-Esteem Scale (SISE) showed good convergent validity with other assessments of self-esteem such as the Rosenberg Self-Esteem Scale [74]. Due to the single-item composition of the SISE, internal 
consistency is supposed to be perfect by definition and cannot be estimated. In this sample, this scale was normally distributed.

Age, gender (male or female), marital status (single, in a relationship — married, in a relationship — not married, widow, or widower), and sexual orientation (measured with a question asking whether the subject described himself or herself as heterosexual, homosexual, or bisexual) were also assessed.

\section{Analyses}

Due to the small sample size for sexual orientation and marital status, demographics were compared between men and women by using the Fisher exact test, whereas the Wilcoxon rank sum test was performed for age. Regarding the different scales, when missing items represented less than or equal to $10 \%$ of all items on a specific scale (16.6\% for the SDHS because it has only 6 items), the missing answer was replaced with the mean of the subject's responses to the items on that scale (person-mean imputation). Internal consistency was assessed with Cronbach alpha [75]. To assess the variables associated with a high score on the CIUS, we performed a linear mixed model. The dependent variable was the CIUS score, and the independent variables were the SDI score, the SDHS score, the ECR-R subscales, the UPPS-P subscales, the SISE, sex, and sexual orientation. An interaction term between sex and sexual orientation was also included in the model. As there were 19 subjects who did not report their year of birth, age was not included in the model. This should not introduce bias into the analysis because the correlation between age and the CIUS score was close to 0 and did not reach statistical significance.

A linear mixed model is a statistical model containing both fixed effects, as in a classical linear regression, and random effects [76]. Random effects are useful for modeling cluster data; therefore, this type of model is suitable for correlated measurements, as it accounts for the lack of independence of the observations. In this sample, it could be assumed that subjects who filled in the French version of the questionnaire were more similar to one another than subjects who filled in the English version of the questionnaire; therefore, language was modeled as a random effect.

To determine whether the tested model was valid, we performed residual analyses and collinearity diagnostics. Residual analysis showed graphically that residuals were normally distributed, that there were no extreme values, and that they were homoscedastic. Regarding collinearity diagnostics, no variance inflation factor was higher than 4 , which suggests that no collinearity problems were present [77]. Analyses were done with R 3.1.0 (R Core Team, 2014) [78]. The package nlme (R Core Team, 2017) was used to run the linear mixed model.

\section{Results}

\section{Demographics of the Participants}

The study involved 145 participants. When we compared the 145 included subjects with those who at least provided their age, sex, and sexual orientation, no statistical differences were found.

Table 1 shows the demographics of the participants. The sample was composed of $60.0 \%$ (87/145) men and $40.0 \%$ (58/145) women. The median age of the sample was 31 years (range: $18-70$ years). Women were younger than men (28 years vs 36.5 years, respectively, $P=.014)$. Regarding marital status, $37.9 \%$ $(55 / 145)$ of the participants were single, $39.3 \%(57 / 145)$ in a relationship_not married, $20.7 \%(30 / 145)$ in a relationship - married, and $2.1 \%$ (3/145) widows or widowers. Sexual orientation and sexual orientation within sex were also measured: $77.9 \%(113 / 145)$ of the participants reported being heterosexual, $7.6 \%(11 / 145)$ being homosexual, and $14.5 \%$ $(21 / 145)$ being bisexual. Among men, 79\% (69/87) reported being heterosexual, $6 \%$ (6/87) being homosexual, and $13 \%$ (12/87) being bisexual; among women, 75\% (44/58) reported being heterosexual, $8 \%(5 / 58)$ being homosexual, and $15 \%$ (9/58) being bisexual.

Table 1. Demographics of the participants.

\begin{tabular}{|c|c|c|c|c|}
\hline Characteristic & Whole sample & Women $(\mathrm{n}=58)$ & Men $(n=87)$ & $P$ value \\
\hline Age, median (range) & $31(18-70)$ & $28(18-70)$ & $36.5(18-70)$ & $.014^{\mathrm{a}}$ \\
\hline Sexual orientation ${ }^{\mathbf{b}}, \mathbf{n}(\%)$ & & & & 0.87 \\
\hline Heterosexual & $113(77.9)$ & $44(38.9)$ & $69(61.1)$ & \\
\hline Homosexual & $11(7.6)$ & $5(45.5)$ & $6(54.5)$ & \\
\hline Bisexual & $21(14.5)$ & $9(42.9)$ & $12(57.1)$ & \\
\hline Marital status $^{\mathbf{c}}, \mathbf{n}(\%)$ & & & & 0.49 \\
\hline Single & $58(40.0)$ & $21(36.2)$ & $37(63.8)$ & \\
\hline In a relationship & $87(60.0)$ & $37(42.5)$ & $50(57.5)$ & \\
\hline
\end{tabular}

${ }^{\mathrm{a}} \mathrm{W}$ statistic for the Wilcoxon rank sum test is 2500.5.

${ }^{\mathrm{b}}$ Women/men proportions are within sexual orientation categories.

${ }^{\mathrm{c}}$ Women/men percentages are within marital status categories. 


\section{Instruments}

Table 2 shows the means and SDs of the instruments used as well as Cronbach alpha [75] as a measure of internal consistency and its $95 \%$ confidence interval. Every instrument had good $(>0.80)$ to excellent $(>0.90)$ internal consistency, but the UPPS-P positive urgency scale fell into the acceptable range $(>0.70)$.

\section{Results of the Linear Mixed Model}

The results of the linear mixed model are reported in Table 3. The most important influences on the CIUS scores (see standardized coefficients) were lower SDHS scores (meaning more depressive scores), followed by higher avoidant attachment style scores, male gender, and higher sexual desire. The other variables (anxious attachment, UPPS-P subscales, SIUS, sexual orientation, and interaction between gender and sexual orientation) did not reach statistical significance on the CIUS scores.

Table 2. Description of the instruments.

\begin{tabular}{|c|c|c|c|}
\hline Instrument & Mean (SD) & Cronbach alpha & $95 \% \mathrm{CI}$ \\
\hline Compulsive Internet Use Scale & $14.64(9.84)$ & .89 & $0.89-0.91$ \\
\hline Sexual Desire Inventory & $70.83(17.66)$ & .87 & $0.84-0.90$ \\
\hline Short Depression-Happiness Scale & $11.29(4.38)$ & .86 & $0.83-0.90$ \\
\hline \multicolumn{4}{|c|}{ Experiences in Close Relationships-Revised questionnaire } \\
\hline Anxious attachment & $3.39(1.33)$ & .92 & $0.91-0.94$ \\
\hline Avoidant attachment & $3.07(1.04)$ & .89 & $0.86-0.91$ \\
\hline \multicolumn{4}{|l|}{ UPPS-P ${ }^{\mathrm{a}}$ Impulsive Behavior Scale } \\
\hline Positive urgency & $10.44(2.57)$ & .74 & $0.67-0.81$ \\
\hline Negative urgency & $8.64(3.04)$ & .86 & $0.82-0.89$ \\
\hline Lack of premeditation & $7.45(2.64)$ & .80 & $0.75-0.85$ \\
\hline Lack of perseverance & $7.34(2.66)$ & .84 & $0.80-0.88$ \\
\hline Sensation seeking & $11.31(2.70)$ & .80 & $0.74-0.85$ \\
\hline Single-Item Self-Esteem Scale & $2.61(0.83)$ & $-\mathrm{b}$ & - \\
\hline
\end{tabular}

${ }^{\mathrm{a} U r g e n c y, ~ P r e m e d i t a t i o n ~(l a c k ~ o f), ~ P e r s e v e r a n c e ~(l a c k ~ o f), ~ S e n s a t i o n ~ S e e k i n g, ~ P o s i t i v e ~ U r g e n c y . ~}$

${ }^{\mathrm{b}}$ Not applicable. 
Table 3. Results of the linear mixed model.

\begin{tabular}{|c|c|c|c|c|c|}
\hline Characteristics and measures & Regression coefficient & Standard error & $\begin{array}{l}t \text { value (degrees of } \\
\text { freedom) }\end{array}$ & $P$ value & Standardized coefficients \\
\hline Female versus male & -3.82 & 1.75 & $-2.18(128)$ & .03 & -0.19 \\
\hline \multicolumn{6}{|c|}{ Sexual orientation (reference group: heterosexual) } \\
\hline Homosexual & 0.08 & 3.67 & $0.02(128)$ & .98 & 0.07 \\
\hline Bisexual & -1.37 & 2.61 & $-0.52(128)$ & 60 & 0.10 \\
\hline \multicolumn{6}{|l|}{ Interaction (female) } \\
\hline Homosexual & 1.62 & 5.58 & $0.29(128)$ & .77 & 0.08 \\
\hline Bisexual & 5.81 & 4.13 & $1.41(128)$ & .16 & 0.29 \\
\hline Sexual Desire Inventory & $0.11^{\mathrm{a}}$ & 0.04 & $2.48(128)$ & .01 & 0.19 \\
\hline Self-esteem & -0.68 & 1.00 & $-0.67(128)$ & .50 & -0.06 \\
\hline \multicolumn{6}{|l|}{ UPPS-P ${ }^{b}$ Impulsive Behavior Scale } \\
\hline Positive urgency & 0.19 & 0.33 & $0.57(128)$ & .57 & 0.06 \\
\hline Negative urgency & -0.15 & 0.37 & $-0.39(128)$ & .69 & -0.04 \\
\hline Lack of premeditation & 0.31 & 0.34 & $0.92(128)$ & .35 & 0.08 \\
\hline Lack of perseverance & -0.07 & 0.36 & $-0.20(128)$ & .84 & -0.02 \\
\hline Sensation seeking & 0.07 & 0.30 & $0.25(128)$ & .80 & 0.02 \\
\hline Short Depression-Happiness Scale & -0.85 & 0.22 & $-3.95(128)$ & $>.001$ & -0.38 \\
\hline \multicolumn{6}{|c|}{ Experiences in Close Relationships-Revised } \\
\hline Anxiety & -0.56 & 0.70 & $-0.81(128)$ & .42 & -0.08 \\
\hline Avoidance & 2.20 & 0.79 & $2.79(128)$ & .006 & 0.23 \\
\hline
\end{tabular}

${ }^{\mathrm{a}}$ Italics represents significant regression parameters.

${ }^{\mathrm{b}}$ Urgency, Premeditation (lack of), Perseverance (lack of), Sensation Seeking, Positive Urgency.

\section{Discussion}

\section{Principal Findings}

The aim of this study was to study cybersex addiction and to assess the links between cybersex addiction and possible determinants of such behavior, namely, sexual desire, mood, attachment style, and impulsivity, by taking into account the age, sex, and sexual orientation of cybersex users. We concluded that addictive cybersex use, as assessed by the CIUS adapted for sexual activities, is associated with sexual desire, depressive mood, an avoidant attachment style, and male gender. As shown in Table 3 (standardized coefficients), the results suggest that the most important influence on the CIUS scores is depressive mood, followed by avoidant attachment style, male gender, and sexual desire. UPPS-P impulsivity subscores, self-esteem, and sexual orientation do not have a significant influence on addictive cybersex.

Sexual desire is an important drive for sexual behavior and is positively associated with emotional intimacy [79]. In this study, elevated sexual desire was significantly associated with addictive cybersex use. This finding is consistent with the gratification hypothesis [26] and with previous findings showing an association between cybersex use and arousal and craving for specific porn cues [80]. The results suggest that at least part of addictive cybersex use is linked to such positive reinforcement.
Sexual desire is also known for its modification related to depressive mood [81]. Possible fluctuations between sexual desire, mood modification, and cybersex use could be assessed in future studies by using methods that are based on ecological momentary assessment [82].

Our finding of an association between addictive cybersex use and depressive mood is congruent with other studies that showed the importance of links between addictive cybersex and diverse assessments of psychological distress and mood $[22,26]$. This finding is also in line with other reports of the association between excessive internet gaming [83] or internet gambling [21] and depressive mood. Such associations suggest that addictive cybersex is at least partly a coping behavior that aims to regulate negative emotions $[20,35,36,84]$. This finding opens the debate, as has occurred for other internet addictive-like behaviors, about an appropriate diagnostic framework [16] and adequate understanding of such an association [85]. The possible development of psychopathological distress, which could lead to a more pronounced depressive mood secondary to the negative impact of addictive cybersex (interpersonal isolation and reduction of offline sexual activities), cannot be ruled out [86], and thus, further prospective studies are warranted.

We also found an association between addictive cybersex use and avoidant attachment but not anxious attachment. These results are congruent with those of other studies showing the 
implications of insecure attachment in excessive internet use [19] and cybersex [41]. Beutel et al [42] found an increase in the intensity of internet sex use with the importance of anxious attachment. Their results failed, however, to reach statistical significance for the link between the importance of internet sex use and avoidant attachment. Such differences could possibly be explained by differences in cybersex use assessment methods. In fact, Beutel et al's study used more items related to cybersex use (eg," I have searched for sexual materials online...") and only 2 items related to addictive cybersex (ie, "I believe that I am an internet sex addict" and "I have promised myself to stop using the internet for sexual purposes"). Furthermore, items were on a dichotomous scale (true or false), which may limit the ability to detect variability. The association found with avoidant attachment could be explained by displeasure and fear of close relationships, which lead to an increase in cybersex activities that less often involve closeness in relationships. In this study, the lack of association between addictive cybersex and anxious attachment style was possibly because of the limitations in sample size. One could hypothesize differences in attachment style across specific cybersex activities (ie, anxious attachment may have more Web-based interactions with potential partners because of anticipated fear of rejections). Further studies should assess specific cybersex activities in more detail. Despite such differences across studies, insecure attachment styles play an important role in cybersex addiction. As suggested elsewhere [19], such findings deserve clinical investigation and treatment of attachment style for patients who are involved in addictive cybersex.

Impulsivity and cybersex addiction were not significantly associated in our study. The results of the study at hand contrast with those of other studies regarding the links between the UPPS-P and internet-related addictive behaviors [21,45]. The results of this study are contrary to those of previous studies showing some associations between addictive cybersex and impulsivity $[20,46]$. Furthermore, using the same UPPS-P scale, Wery et al [20] showed that in a group of male participants, negative urgency interacted with negative affects in predicting addictive cybersex. However, the strength of the association was not strong, as shown by the authors' reported odds ratio of 1.03 (95\% CI=1.01-1.06). In another study, Wetterneck et al [46] showed a small correlation between a measure of impulsivity and the number of hours of porn use by week. However, they did not report significant differences in impulsivity between a group of addictive porn users and controls.

In light of such observations across studies, one may hypothesize that some impulsivity facets may contribute to addictive cybersex without having a main determinant effect on such behavior. This may contribute to disparities between studies. Furthermore, such differences are possibly influenced by sample size, the specific type of cybersex activities (ie, possible differences between porn use and sex dating), and other assessments involved in the analyses. For instance, our study included measures of attachment, a construct not included in the previously mentioned studies. However, we cannot exclude the possibility of modifications in executive functions when an individual faces specific cybersex cues [24] or during interactions with negative states and cybersex use [20]. Further studies on the possible role of impulsivity constructs in addictive cybersex are needed.

Self-esteem had no impact on CIUS scores. This result contradicts those of other studies that show, for instance, an association between low self-esteem and adolescent sexting (sharing sexual photos) [32]. These differences between studies may be because of sample characteristics, participants' specific cybersex activities, or the assessment methods. This study, for example, assessed general self-esteem with only 1 question. Furthermore, the impact of specific cybersex activities on self-esteem cannot be ruled out. Prospective studies on the links between such activities and self-esteem, including possible mediators of effects such as fear of negative evaluation [33], are needed.

This study also showed an association between addictive cybersex and male gender, as has repeatedly been found $[17,42,46,87,88]$. Sociocultural differences may contribute to this phenomenon. Moreover, possible differences between men and women in sexual desire, sexual arousal, and their interplay may contribute to the observed difference [89]. The design of sex-related websites and mobile phones apps may also influence gender differences in cybersex use. Gender differences were commonly reported in addictive disorders; additional studies are required to understand the underlying mechanisms [90].

Among a population of cybersex users, our study showed no association between age and cybersex addiction. Most studies on cybersex have involved adolescents and young adults [17]. Some earlier studies (in the early 2000s), however, showed that adults older than 50 years were less prone to cybersex use than younger adults [91]. The findings of this study are possibly explained by a focus on cybersex addiction (and not on cybersex use) and by societal evolution and wider access to the internet in all age ranges.

In this study, sexual orientation had no effect on the assessed behavior. Similarly, no effect was found in the interactions between gender and sexual orientation. However, sexual orientation was assessed in only 3 main categories (heterosexual, bisexual, and homosexual). Future studies would benefit from more refined evaluations of sexual orientation [51] and its possible components (eg, erotic fantasy and social interactions) [92] as well as from evaluations of gender identity and its related distress [93].

Cybersex is associated with addictive use for only a small number of users [20]. This observation is also illustrated by the mean (Table 2) and median (13 of 56) of the CIUS scores in this study. Nonetheless, for those with addictive patterns of use, treatment options are still sparse and understudied; most of the few preliminary studies in the field have tried to reproduce what is already known from the psychotherapy of addictive disorders [12].

The findings of this study have clinical implications. It seems important to consider cybersex addiction in terms of its principal connections with several psychological dimensions. Particular attention should be given to the patient's patterns of attachment. Psychotherapeutic treatment has to be tailored to the specific 
needs of each patient. People with avoidant attachment, for example, may benefit from a psychotherapeutic approach designed to integrate treatment of addiction and attachment disturbances. Future studies for the assessment and treatment of cybersex addiction are needed in clinical settings.

\section{Limitations}

Several limitations of the study must be considered. The sample was relatively small but adequate for the study statistics. Furthermore, the sample was exposed to self-selection biases [94]. The cross-sectional design did not allow assessment of longitudinal interplay between the assessed variables. Furthermore, the study did not take into consideration the different cybersex activities that could influence cybersex use across different behaviors and cybersex communities. Finally, there is no consensus related to cybersex addiction, and thus, the study used the CIUS adapted to cybersex as a proxy. Using a continuous approach rather than a categorical one, however, allows assessment of some determinants of the severity of addictive cybersex use with an adequate research instrument related to addictive use of internet-delivered services.

\section{Conclusions}

Despite these limitations, this study indicates that addictive cybersex is influenced by an avoidant attachment style, depressive mood, and sexual desire. Males are at increased risk. Self-esteem and impulsivity do not seem to have a significant influence on addictive cybersex. Further research, including prospective studies, is needed in the field.

\section{Acknowledgments}

No funding was received for this study. The authors thank the study participants.

\section{Authors' Contributions}

NV, YK, FBD, and SR were involved in the study concept and design. SR, YK, and NV were involved in statistical analysis and interpretation of data. TL, KJ, and YK were involved in the recruitment of participants. NV, YK, KJ, TL, SR, and FBD were involved in writing of the manuscript.

\section{Conflicts of Interest}

None declared.

\section{References}

1. Khazaal Y, Chatton A, Cochand S, Jermann F, Osiek C, Bondolfi G, et al. Quality of web-based information on pathological gambling. J Gambl Stud 2008 Sep;24(3):357-366. [doi: 10.1007/s10899-008-9095-7] [Medline: 18373182]

2. Van Singer M, Chatton A, Khazaal Y. Quality of smartphone apps related to panic disorder. Front Psychiatry 2015 Jul 14;6:96 [FREE Full text] [doi: 10.3389/fpsyt.2015.00096] [Medline: 26236242]

3. Greiner C, Chatton A, Khazaal Y. Online self-help forums on cannabis: a content assessment. Patient Educ Couns 2017 Oct;100(10):1943-1950. [doi: 10.1016/j.pec.2017.06.001] [Medline: 28602568]

4. Zermatten A, Khazaal Y, Coquard O, Chatton A, Bondolfi G. Quality of web-based information on depression. Depress Anxiety 2010 Sep;27(9):852-858. [doi: 10.1002/da.20665] [Medline: 20099271]

5. von Rosen AJ, von Rosen FT, Tinnemann P, Müller-Riemenschneider F. Sexual health and the internet: cross-sectional study of online preferences among adolescents. J Med Internet Res 2017 Dec 08;19(11):e379 [FREE Full text] [doi: 10.2196/jmir.7068] [Medline: 29117927]

6. Döring NM. The internet's impact on sexuality: a critical review of 15 years of research. Comput Human Behav 2009 Sep 01;25(5):1089-1101. [doi: 10.1016/j.chb.2009.04.003]

7. Shaughnessy K, Byers ES, Walsh L. Online sexual activity experience of heterosexual students: gender similarities and differences. Arch Sex Behav 2011 Apr;40(2):419-427. [doi: 10.1007/s10508-010-9629-9] [Medline: 20467798]

8. Grov C, Gillespie BJ, Royce T, Lever J. Perceived consequences of casual online sexual activities on heterosexual relationships: a US online survey. Arch Sex Behav 2011 Apr;40(2):429-439. [doi: 10.1007/s10508-010-9598-z] [Medline: 20174862]

9. Khazaal Y, Chatton A, Rothen S, Achab S, Thorens G, Zullino D, et al. Psychometric properties of the 7-item game addiction scale among french and German speaking adults. BMC Psychiatry 2016 May 10;16:132 [FREE Full text] [doi: 10.1186/s12888-016-0836-3] [Medline: 27160387]

10. Weinstein AM. An update overview on brain imaging studies of internet gaming disorder. Front Psychiatry 2017 Sep 29;8:185 [FREE Full text] [doi: 10.3389/fpsyt.2017.00185] [Medline: 29033857]

11. Petry NM, O'Brien CP. Internet gaming disorder and the DSM-5. Addiction 2013 Jul;108(7):1186-1187. [doi: 10.1111/add.12162] [Medline: 23668389]

12. Wéry A, Billieux J. Problematic cybersex: conceptualization, assessment, and treatment. Addict Behav 2017 Jan;64:238-246. [doi: 10.1016/j.addbeh.2015.11.007] [Medline: 26646983]

13. Weinstein AM, Zolek R, Babkin A, Cohen K, Lejoyeux M. Factors predicting cybersex use and difficulties in forming intimate relationships among male and female users of cybersex. Front Psychiatry 2015 Apr 20;6:54 [FREE Full text] [doi: 10.3389/fpsyt.2015.00054] [Medline: 25941496] 
14. Karila L, Wéry A, Weinstein A, Cottencin O, Petit A, Reynaud M, et al. Sexual addiction or hypersexual disorder: different terms for the same problem? A review of the literature. Curr Pharm Des 2014;20(25):4012-4020. [doi: 10.2174/13816128113199990619] [Medline: 24001295]

15. Carnes PJ. Cybersex, courtship, and escalating arousal: factors in addictive sexual desire. Sex Addict Compulsivity 2011 Oct 13;8(1):45-78. [doi: 10.1080/10720160127560]

16. Kraus SW, Voon V, Potenza MN. Should compulsive sexual behavior be considered an addiction? Addiction 2016 Dec;111(12):2097-2106 [FREE Full text] [doi: 10.1111/add.13297] [Medline: 26893127]

17. Ballester-Arnal R, Castro CJ, Gil-Llario MD, Gil-Julia B. Cybersex addiction: a study on Spanish college students. J Sex Marital Ther 2017 Aug 18;43(6):567-585. [doi: 10.1080/0092623X.2016.1208700] [Medline: 27398694]

18. Green BA, Carnes S, Carnes PJ, Weinman EA. Cybersex addiction patterns in a clinical sample of homosexual, heterosexual, and bisexual men and women. Sex Addict Compulsivity 2012 Jan;19(1-2):77-98. [doi: 10.1080/10720162.2012.658343]

19. Eichenberg C, Schott M, Decker O, Sindelar B. Attachment style and internet addiction: an online survey. J Med Internet Res 2017 May 17;19(5):e170 [FREE Full text] [doi: 10.2196/jmir.6694] [Medline: 28526662]

20. Wéry A, Deleuze J, Canale N, Billieux J. Emotionally laden impulsivity interacts with affect in predicting addictive use of online sexual activity in men. Compr Psychiatry 2018 Jan;80:192-201. [doi: 10.1016/j.comppsych.2017.10.004] [Medline: 29128857]

21. Khazaal Y, Chatton A, Achab S, Monney G, Thorens G, Dufour M, et al. Internet gamblers differ on social variables: a latent class analysis. J Gambl Stud 2017 Sep;33(3):881-897. [doi: 10.1007/s10899-016-9664-0] [Medline: 28028687]

22. Bancroft J, Vukadinovic Z. Sexual addiction, sexual compulsivity, sexual impulsivity, or what? Toward a theoretical model. J Sex Res 2004 Aug;41(3):225-234. [doi: 10.1080/00224490409552230] [Medline: 15497051]

23. Brand M, Snagowski J, Laier C, Maderwald S. Ventral striatum activity when watching preferred pornographic pictures is correlated with symptoms of Internet pornography addiction. Neuroimage 2016 Apr 01;129:224-232. [doi:

10.1016/j.neuroimage.2016.01.033] [Medline: 26803060]

24. Brand M, Young KS, Laier C. Prefrontal control and internet addiction: a theoretical model and review of neuropsychological and neuroimaging findings. Front Hum Neurosci 2014 May 27;8:375 [FREE Full text] [doi: 10.3389/fnhum.2014.00375] [Medline: 24904393]

25. Brand M, Laier C, Pawlikowski M, Schächtle U, Schöler T, Altstötter-Gleich C. Watching pornographic pictures on the internet: role of sexual arousal ratings and psychological-psychiatric symptoms for using internet sex sites excessively. Cyberpsychol Behav Soc Netw 2011 Jun;14(6):371-377. [doi: 10.1089/cyber.2010.0222] [Medline: 21117979]

26. Laier C, Pekal J, Brand M. Cybersex addiction in heterosexual female users of internet pornography can be explained by gratification hypothesis. Cyberpsychol Behav Soc Netw 2014 Aug;17(8):505-511. [doi: 10.1089/cyber.2013.0396] [Medline: 25080011]

27. Voon V, Mole TB, Banca P, Porter L, Morris L, Mitchell S, et al. Neural correlates of sexual cue reactivity in individuals with and without compulsive sexual behaviours. PLoS One 2014 Jul 11;9(7):e102419 [FREE Full text] [doi: 10.1371/journal.pone.0102419] [Medline: 25013940]

28. Laier C, Pekal J, Brand M. Sexual excitability and dysfunctional coping determine cybersex addiction in homosexual males. Cyberpsychol Behav Soc Netw 2015 Oct;18(10):575-580. [doi: 10.1089/cyber.2015.0152] [Medline: 26374928]

29. Levine SB. The nature of sexual desire: a clinician's perspective. Arch Sex Behav 2003 Jun;32(3):279-285. [doi: 10.1023/A:1023421819465] [Medline: 12807300]

30. Bancroft J, Graham CA, Janssen E, Sanders SA. The dual control model: current status and future directions. J Sex Res 2009;46(2-3):121-142. [doi: 10.1080/00224490902747222] [Medline: 19308839]

31. Bousoño Serrano M, Al-Halabí S, Burón P, Garrido M, Díaz-Mesa EM, Galván G, et al. Substance use or abuse, internet use, psychopathology and suicidal ideation in adolescents. Adicciones 2017 Jan 12;29(2):97-104 [FREE Full text] [doi: 10.20882/adicciones.811] [Medline: 28170053]

32. Ybarra ML, Mitchell KJ. "Sexting" and its relation to sexual activity and sexual risk behavior in a national survey of adolescents. J Adolesc Health 2014 Dec;55(6):757-764 [FREE Full text] [doi: 10.1016/j.jadohealth.2014.07.012] [Medline: 25266148]

33. Biolcati R. The role of self-esteem and fear of negative evaluation in compulsive buying. Front Psychiatry 2017 May 02;8:74 [FREE Full text] [doi: 10.3389/fpsyt.2017.00074] [Medline: 28512435]

34. Andreassen CS, Pallesen S, Griffiths MD, Torsheim T, Sinha R. The development and validation of the Bergen-Yale sex addiction scale with a large national sample. Front Psychol 2018 Mar 08;9:144 [FREE Full text] [doi:

10.3389/fpsyg.2018.00144] [Medline: 29568277]

35. Zanetta Dauriat F, Zermatten A, Billieux J, Thorens G, Bondolfi G, Zullino D, et al. Motivations to play specifically predict excessive involvement in massively multiplayer online role-playing games: evidence from an online survey. Eur Addict Res 2011;17(4):185-189. [doi: 10.1159/000326070] [Medline: 21494046]

36. Cooper A, Galbreath N, Becker MA. Sex on the internet: furthering our understanding of men with online sexual problems. Psychol Addict Behav 2004 Sep;18(3):223-230. [doi: 10.1037/0893-164X.18.3.223] [Medline: 15482077]

37. Berry K, Varese F, Bucci S. Cognitive attachment model of voices: evidence base and future implications. Front Psychiatry 2017 Jun 30;8:111 [FREE Full text] [doi: 10.3389/fpsyt.2017.00111] [Medline: 28713292] 
38. Falgares G, Marchetti D, De Santis S, Carrozzino D, Kopala-Sibley DC, Fulcheri M, et al. Attachment styles and suicide-related behaviors in adolescence: the mediating role of self-criticism and dependency. Front Psychiatry 2017 Mar;8:36 [FREE Full text] [doi: 10.3389/fpsyt.2017.00036] [Medline: 28344562]

39. Mark KP, Vowels LM, Murray SH. The impact of attachment style on sexual satisfaction and sexual desire in a sexually diverse sample. J Sex Marital Ther 2017 Nov 22;44(5):1-9. [doi: 10.1080/0092623X.2017.1405310] [Medline: 29166227]

40. Weinstein A, Katz L, Eberhardt H, Cohen K, Lejoyeux M. Sexual compulsion--relationship with sex, attachment and sexual orientation. J Behav Addict 2015 Mar;4(1):22-26 [FREE Full text] [doi: 10.1556/JBA.4.2015.1.6] [Medline: 25786496]

41. Kor A, Zilcha-Mano S, Fogel YA, Mikulincer M, Reid RC, Potenza MN. Psychometric development of the Problematic Pornography Use Scale. Addict Behav 2014 May;39(5):861-868. [doi: 10.1016/j.addbeh.2014.01.027] [Medline: 24583276]

42. Beutel ME, Giralt S, Wölfling K, Stöbel-Richter Y, Subic-Wrana C, Reiner I, et al. Prevalence and determinants of online-sex use in the German population. PLoS One 2017 Jun 19;12(6):e0176449. [doi: 10.1371/journal.pone.0176449] [Medline: 28628620]

43. Rochat L, Billieux J, Gagnon J, Van der Linden M. A multifactorial and integrative approach to impulsivity in neuropsychology: insights from the UPPS model of impulsivity. J Clin Exp Neuropsychol 2018 Feb;40(1):45-61. [doi: 10.1080/13803395.2017.1313393] [Medline: 28398126]

44. Rothen S, Briefer J, Deleuze J, Karila L, Andreassen CS, Achab S, et al. Disentangling the role of users' preferences and impulsivity traits in problematic Facebook use. PLoS One 2018 Sep 05;13(9):e0201971 [FREE Full text] [doi: 10.1371/journal.pone.0201971] [Medline: 30183698]

45. Billieux J, Chanal J, Khazaal Y, Rochat L, Gay P, Zullino D, et al. Psychological predictors of problematic involvement in massively multiplayer online role-playing games: illustration in a sample of male cybercafé players. Psychopathology 2011;44(3):165-171. [doi: 10.1159/000322525] [Medline: 21372629]

46. Wetterneck CT, Burgess AJ, Short MB, Smith AH, Cervantes ME. The role of sexual compulsivity, impulsivity, and experiential avoidance in internet pornography use. Psychol Rec 2017 May 29;62(1):3-18. [doi: 10.1007/BF03395783]

47. Billieux J, Rochat L, Ceschi G, Carré A, Offerlin-Meyer I, Defeldre A, et al. Validation of a short French version of the UPPS-P Impulsive Behavior Scale. Compr Psychiatry 2012 Jul;53(5):609-615. [doi: 10.1016/j.comppsych.2011.09.001] [Medline: 22036009]

48. D'Orta I, Burnay J, Aiello D, Niolu C, Siracusano A, Timpanaro L, et al. Development and validation of a short Italian UPPS-P Impulsive Behavior Scale. Addict Behav Rep 2015 Dec;2:19-22 [FREE Full text] [doi: 10.1016/j.abrep.2015.04.003] [Medline: 29531990]

49. Cyders MA, Littlefield AK, Coffey S, Karyadi KA. Examination of a short English version of the UPPS-P Impulsive Behavior Scale. Addict Behav 2014 Sep;39(9):1372-1376 [FREE Full text] [doi: 10.1016/j.addbeh.2014.02.013] [Medline: 24636739]

50. Bteich G, Berbiche D, Khazaal Y. Validation of the short Arabic UPPS-P Impulsive Behavior Scale. BMC Psychiatry 2017 Dec 06;17(1):244 [FREE Full text] [doi: 10.1186/s12888-017-1407-y] [Medline: 28683772]

51. Moser C. Defining sexual orientation. Arch Sex Behav 2016 Apr;45(3):505-508. [doi: 10.1007/s10508-015-0625-y] [Medline: 26408011]

52. Ybarra ML, Mitchell KJ. A national study of lesbian, gay, bisexual (LGB), and non-LGB youth sexual behavior online and in-person. Arch Sex Behav 2016 Aug;45(6):1357-1372 [FREE Full text] [doi: 10.1007/s10508-015-0491-7] [Medline: $\underline{25894645]}$

53. Roth EA, Cui Z, Wang L, Armstrong HL, Rich AJ, Lachowsky NJ, et al. Substance use patterns of gay and bisexual men in the Momentum Health study. Am J Mens Health 2018 Sep;12(5):1759-1773 [FREE Full text] [doi: 10.1177/1557988318786872] [Medline: 30024296]

54. Li Y, Yuan Z, Clements-Nolle K, Yang W. Sexual orientation and depressive symptoms among high school students in Jiangxi province. Asia Pac J Public Health 2018 Sep 15:1010539518800335 (forthcoming). [doi: 10.1177/1010539518800335] [Medline: 30221972]

55. Meerkerk G, Van Den Eijnden RJ, Vermulst AA, Garretsen HF. The Compulsive Internet Use Scale (CIUS): some psychometric properties. Cyberpsychol Behav 2009 Feb;12(1):1-6. [doi: 10.1089/cpb.2008.0181] [Medline: 19072079]

56. Khazaal Y, Chatton A, Horn A, Achab S, Thorens G, Zullino D, et al. French validation of the compulsive internet use scale (CIUS). Psychiatr Q 2012 Dec;83(4):397-405. [doi: 10.1007/s11126-012-9210-x] [Medline: 22367623]

57. Khazaal Y, Chatton A, Atwi K, Zullino D, Khan R, Billieux J. Arabic validation of the Compulsive Internet Use Scale (CIUS). Subst Abuse Treat Prev Policy 2011 Nov 29;6:32 [FREE Full text] [doi: 10.1186/1747-597X-6-32] [Medline: 22126679]

58. Guertler D, Broda A, Bischof A, Kastirke N, Meerkerk G, John U, et al. Factor structure of the compulsive internet use scale. Cyberpsychol Behav Soc Netw 2014 Jan;17(1):46-51. [doi: 10.1089/cyber.2013.0076] [Medline: 23962124]

59. Dhir A, Chen S, Nieminen M. Psychometric validation of the Chinese Compulsive Internet Use Scale (CIUS) with Taiwanese high school adolescents. Psychiatr Q 2015 Dec;86(4):581-596. [doi: 10.1007/s11126-015-9351-9] [Medline: 25736798]

60. Khazaal Y, Achab S, Billieux J, Thorens G, Zullino D, Dufour M, et al. Factor structure of the internet addiction test in online gamers and poker players. JMIR Ment Health 2015 Apr 22;2(2):e12 [FREE Full text] [doi: 10.2196/mental.3805] [Medline: 26543917] 
61. Downing Jr MJ, Antebi N, Schrimshaw EW. Compulsive use of internet-based sexually explicit media: adaptation and validation of the Compulsive Internet Use Scale (CIUS). Addict Behav 2014 Jun;39(6):1126-1130 [FREE Full text] [doi: 10.1016/j.addbeh.2014.03.007] [Medline: 24679612]

62. Spector IP, Carey MP, Steinberg L. The sexual desire inventory: development, factor structure, and evidence of reliability. J Sex Marital Ther 1996;22(3):175-190. [doi: 10.1080/00926239608414655] [Medline: 8880651]

63. Joseph S, Linley PA, Harwood J, Lewis CA, McCollam P. Rapid assessment of well-being: the Short Depression-Happiness Scale (SDHS). Psychol Psychother 2004 Dec;77(Pt 4):463-478. [doi: 10.1348/1476083042555406] [Medline: 15588455]

64. Fraley RC, Waller NG, Brennan KA. An item response theory analysis of self-report measures of adult attachment. J Pers Soc Psychol 2000 Feb;78(2):350-365. [doi: 10.1037/0022-3514.78.2.350] [Medline: 10707340]

65. Lafontaine MF, Lussier Y. [Bidimensional structure of attachment in love: anxiety over abandonment and avoidance of intimacy]. Can J Behav Sci 2003 Jan 01;35(1):56-60.

66. Ravitz P, Maunder R, Hunter J, Sthankiya B, Lancee W. Adult attachment measures: a 25-year review. J Psychosom Res 2010 Oct;69(4):419-432. [doi: 10.1016/j.jpsychores.2009.08.006] [Medline: 20846544]

67. Whiteside SP, Lynam DR. The five factor model and impulsivity: using a structural model of personality to understand impulsivity. Pers Individ Dif 2001;30(4):669-689. [doi: 10.1016/S0191-8869(00)00064-7]

68. Canale N, Vieno A, Bowden-Jones H, Billieux J. The benefits of using the UPPS model of impulsivity rather than the Big Five when assessing the relationship between personality and problem gambling. Addiction 2017 Dec;112(2):372-373. [doi: 10.1111/add.13641] [Medline: 27873374]

69. Coskunpinar A, Dir AL, Cyders MA. Multidimensionality in impulsivity and alcohol use: a meta-analysis using the UPPS model of impulsivity. Alcohol Clin Exp Res 2013 Sep;37(9):1441-1450 [FREE Full text] [doi: 10.1111/acer.12131] [Medline: 23578176]

70. Gunn RL, Jackson KM, Borsari B, Metrik J. Negative urgency partially accounts for the relationship between major depressive disorder and marijuana problems. Borderline Personal Disord Emot Dysregul 2018 May 16;5:10 [ㅍREE Full text] [doi: 10.1186/s40479-018-0087-7] [Medline: 29796282]

71. De-Sola J, Talledo H, Rubio G, de Fonseca FR. Development of a mobile phone addiction craving scale and its validation in a Spanish adult population. Front Psychiatry 2017 May 30;8:90 [FREE Full text] [doi: 10.3389/fpsyt.2017.00090] [Medline: 28611692]

72. Navas JF, Contreras-Rodríguez O, Verdejo-Román J, Perandrés-Gómez A, Albein-Urios N, Verdejo-García A, et al. Trait and neurobiological underpinnings of negative emotion regulation in gambling disorder. Addiction 2017 Jun;112(6):1086-1094. [doi: 10.1111/add.13751] [Medline: 28060454]

73. Rømer Thomsen K, Callesen MB, Hesse M, Kvamme TL, Pedersen MM, Pedersen MU, et al. Impulsivity traits and addiction-related behaviors in youth. J Behav Addict 2018 Jun 01;7(2):317-330 [FREE Full text] [doi: 10.1556/2006.7.2018.22] [Medline: 29642723]

74. Robins R, Hendin H, Trzesniewski K. Measuring global self-esteem: construct validation of a single-item measure and the Rosenberg Self-Esteem Scale. Pers Soc Psychol Bull 2001;27(2):151-161. [doi: 10.1177/0146167201272002]

75. Cronbach LJ, Meehl PE. Construct validity in psychological tests. Psychol Bull 1955;52(4):281-302. [doi: 10.1037/h0040957]

76. Mcculloch CE, Neuhaus JM, Searle SR. Generalized linear mixed models. Hoboken, New Jersey: Wiley; 2014.

77. Fox J, Monette G. Generalized collinearity diagnostics. J Am Stat Assoc 1992 Mar;87(417):178. [doi: 10.2307/2290467]

78. R Core Team. R Foundation. 2014. A language and environment for statistical computing URL: https://www.gbif.org/tool/ 81287/r-a-language-and-environment-for-statistical-computing [accessed 2019-01-15] [WebCite Cache ID 75RB1EqZu]

79. Štulhofer A, Ferreira LC, Landripet I. Emotional intimacy, sexual desire, and sexual satisfaction among partnered heterosexual men. Sex Relation Ther 2013 Dec 23;29(2):229-244. [doi: 10.1080/14681994.2013.870335]

80. Laier C, Pawlikowski M, Pekal J, Schulte FP, Brand M. Cybersex addiction: experienced sexual arousal when watching pornography and not real-life sexual contacts makes the difference. J Behav Addict 2013 Jun;2(2):100-107. [doi: 10.1556/JBA.2.2013.002] [Medline: 26165929]

81. Angst J. Sexual problems in healthy and depressed persons. Int Clin Psychopharmacol 1998 Jul;13 Suppl 6:S1-S4. [Medline: 9728667]

82. Benarous X, Edel Y, Consoli A, Brunelle J, Etter JF, Cohen D, et al. Ecological momentary assessment and smartphone application intervention in adolescents with substance use and comorbid severe psychiatric disorders: study protocol. Front Psychiatry 2016 Sep 20;7:157 [FREE Full text] [doi: 10.3389/fpsyt.2016.00157] [Medline: 27703435]

83. Wei H, Chen MH, Huang PC, Bai YM. The association between online gaming, social phobia, and depression: an internet survey. BMC Psychiatry 2012 Jul 28;12:92 [FREE Full text] [doi: 10.1186/1471-244X-12-92] [Medline: 22839747]

84. Paul B, Shim JW. Gender, sexual affect, and motivations for internet pornography use. Int J Sex Health 2008 Oct 12;20(3):187-199. [doi: 10.1080/19317610802240154]

85. Starcevic V, Khazaal Y. Relationships between behavioural addictions and psychiatric disorders: what is known and what is yet to be learned? Front Psychiatry 2017 Apr 07;8:53 [FREE Full text] [doi: 10.3389/fpsyt.2017.00053] [Medline: $\underline{28439243}$ ]

86. Levin ME, Lillis J, Hayes SC. When is online pornography viewing problematic among college males? Examining the moderating role of experiential avoidance. Sex Addict Compulsivity 2012;19(3):168-180. [doi: 10.1080/10720162] 
87. Ballester-Arnal R, Castro-Calvo J, Gil-Llario MD, Giménez-García C. Relationship status as an influence on cybersex activity: cybersex, youth, and steady partner. J Sex Marital Ther 2014;40(5):444-456. [doi: 10.1080/0092623X.2013.772549] [Medline: 24134331]

88. Ross MW, Månsson SA, Daneback K. Prevalence, severity, and correlates of problematic sexual internet use in Swedish men and women. Arch Sex Behav 2012 Apr;41(2):459-466. [doi: 10.1007/s10508-011-9762-0] [Medline: 21562915]

89. Mitchell KR, Wellings KA, Graham C. How do men and women define sexual desire and sexual arousal? J Sex Marital Ther 2014;40(1):17-32. [doi: 10.1080/0092623X.2012.697536] [Medline: 23819590]

90. McHugh RK, Votaw VR, Sugarman DE, Greenfield SF. Sex and gender differences in substance use disorders. Clin Psychol Rev 2017 Nov 10;66:12-23. [doi: 10.1016/j.cpr.2017.10.012] [Medline: 29174306]

91. Daneback K, Cooper A, Månsson SA. An internet study of cybersex participants. Arch Sex Behav 2005 Jun;34(3):321-328. [doi: $10.1007 / \mathrm{s} 10508-005-3120-\mathrm{z}]$ [Medline: 15971014]

92. Bowins B. A four-component model of sexual orientation \& its application to psychotherapy. Am J Psychother 2016;70(3):251-276. [doi: 10.1176/appi.psychotherapy.2016.70.3.251] [Medline: 27662044]

93. Valentine SE, Shipherd JC. A systematic review of social stress and mental health among transgender and gender non-conforming people in the United States. Clin Psychol Rev 2018 Mar 28;66:24-38. [doi: 10.1016/j.cpr.2018.03.003] [Medline: 29627104]

94. Khazaal Y, van Singer M, Chatton A, Achab S, Zullino D, Rothen S, et al. Does self-selection affect samples' representativeness in online surveys? An investigation in online video game research. J Med Internet Res 2014 Jul 07;16(7):e164 [FREE Full text] [doi: 10.2196/jmir.2759] [Medline: 25001007]

\author{
Abbreviations \\ CIUS: Compulsive Internet Use Scale \\ ECR-R: Experiences in Close Relationships-Revised \\ SDHS: Short Depression-Happiness Scale \\ SDI: Sexual Desire Inventory \\ SISE: Single-Item Self-Esteem Scale \\ UPPS-P: Urgency, Premeditation (lack of), Perseverance (lack of), Sensation Seeking, Positive Urgency) Impulsive \\ Behavior Scale
}

\author{
Edited by G Eysenbach; submitted 01.02.18; peer-reviewed by L McDonagh, E Brivio; comments to author 28.07.18; revised version \\ received 01.11.18; accepted 12.12.18; published 21.01.19 \\ Please cite as: \\ Varfi N, Rothen S, Jasiowka K, Lepers T, Bianchi-Demicheli F, Khazaal Y \\ Sexual Desire, Mood, Attachment Style, Impulsivity, and Self-Esteem as Predictive Factors for Addictive Cybersex \\ JMIR Ment Health 2019;6(1):e9978 \\ URL: https://mental.jmir.org/2019/1/e9978/ \\ doi: $10.2196 /$ mental.9978 \\ PMID: $\underline{30664470}$
}

CNektaria Varfi, Stephane Rothen, Katarzyna Jasiowka, Thibault Lepers, Francesco Bianchi-Demicheli, Yasser Khazaal. Originally published in JMIR Mental Health (http://mental.jmir.org), 21.01.2019. This is an open-access article distributed under the terms of the Creative Commons Attribution License (https://creativecommons.org/licenses/by/4.0/), which permits unrestricted use, distribution, and reproduction in any medium, provided the original work, first published in JMIR Mental Health, is properly cited. The complete bibliographic information, a link to the original publication on http://mental.jmir.org/, as well as this copyright and license information must be included. 